University of New Haven

University of

New Haven

Digital Commons@ New Haven

$11-2017$

\title{
The international REIT's time-varying response to the U.S. monetary policy and macroeconomic surprises
}

Hardik Marfatia

Northeastern Illinois University

Rangan Gupta

University of Pretoria

Esin Cakan

University of New Haven, ECakan@newhaven.edu

Follow this and additional works at: https://digitalcommons.newhaven.edu/economics-facpubs Part of the Economics Commons

\section{Publisher Citation}

Marfatia, H. A., Gupta, R., \& Cakan, E. (2017). The international REIT's time-varying response to the US monetary policy and macroeconomic surprises. The North American Journal of Economics and Finance, 42, 640-653.

Comments

This is the authors' accepted version of the published article. The version of record can be found at http://dx.doi.org/10.1016/j.najef.2017.09.007 


\title{
The International REIT's Time-Varying Response to the U.S. Monetary Policy and Macroeconomic Surprises
}

\author{
Hardik A. Marfatia*, Rangan Gupta ${ }^{\dagger}$ and Esin Cakan ${ }^{\ddagger \delta}$
}

August 23, 2017

\begin{abstract}
International real estate markets and the ever increasing role of the U.S. economic and policy developments have played a central role both in international portfolio management as well as broader economic policy making. In this paper, we measure the extent of time-varying impact of the U.S. monetary policy and macroeconomic news on the international Real Estate Investment Trusts (REITs) stock returns. Results suggest that there has been significant variation both across time and across countries in the impact of U.S. news on the global REIT stocks. Further, the country's stock market capitalization to GDP ratio has strong connections with the time-varying nature of the impact of the U.S. news on the global REIT stock returns.
\end{abstract}

JEL Classifications: E44, E52, C32, F42, G14.

Keywords: Monetary Policy, Macroeconomic Surprises, International REITs, Time-Varying Model.

\footnotetext{
*Department of Economics, Northeastern Illinois University, BBH 344G, 5500 N. St. Louis Ave., Chicago, IL 60625, USA. E-mail: h-marfatia@neiu.edu.

$\dagger$ Department of Economics, University of Pretoria, Pretoria, 0002, South Africa. E-mail: rangan.gupta@up.ac.za

$\ddagger$ Department of Economics, University of New Haven, 300 Boston Post Road, West Haven, CT 06516, USA. E-mail: ecakan@newhaven.edu.

$\S$ We acknowledge valuable inputs from two anonymous referees.
} 


\section{Introduction}

Securitized real estate markets, i.e., Real Estate Investment Trusts (REITs) have experienced tremendous growth in the global economy. According to the National Association of Real Estate Investment Trusts (NAREIT), global real estate markets represented more than $\$ 1.22$ trillion of equity capitalization in July of 2016. In addition, with REITs being exchange-traded funds that earn most of their income from investments in real estate, REITs have been the epicenter of research interest since their returns do not suffer from measurement error and high transaction costs compared to other real estate investments. As indicated by Akinsomi et al. (2016b), REITs constitute a very good proxy for the real estate market, providing at the same time high-frequency observable data, since REITs shares trade as common stocks. Since REITs are accessible to all investors irrespective of the portfolio size, this asset class has been particularly successful in attracting investment capital. This paper studies the sensitivity over time of REIT returns of the U.S. economy as well as major international markets with respect to the surprise component of monetary policy (Federal funds futures) and macroeconomic (inflation and unemployment) news announcements of the U.S. economy. ${ }^{1}$ The U.S. has been undoubtedly the most important country in affecting global markets in terms of unanticipated effects of both monetary and macroeconomic surprises (Xu and Yang 2011; Kishor and Marfatia 2013; Cakan et al. 2015; Claus and Dungey 2016).

As pointed out by Kroencke et al. (2016), the relationship between financial markets, including REITs, and macroeconomic information risk can arise through two channels: (a) News on the macroeconomic data is sometimes randomly published, and; (b) More importantly, although news of macroeconomic variables occur on the pre-scheduled date, the precise value of these factors can only be anticipated. Thus, it is important to measure expectations contained in the macroeconomic announcements. In this regard, consensus estimations of professionals are highly trusted and considered to be a reliable source to predict these values. The semi-strong form of the efficient market hypothesis implies that the forecasted values are already included in the pricing of an asset after the consensus data are published, but not the unexpected difference between the predicted and the announced data (i.e., the surprise component).

In addition, different methods have been proposed to estimate monetary policy shocks in the literature. ${ }^{2}$ However, more recently, Federal funds futures rate has received widespread attention,

\footnotetext{
${ }^{1}$ The major international markets includes Australia, Belgium, Canada, France, Japan, Netherlands, New Zealand, and the U.S.. These markets combined constitute $88.3 \%$ of the global REIT index based on market capitalization which includes Australia (8.28\%), Canada (3.14\%), France (1.85\%), Japan (5.93\%), Netherlands (3.05\%), and U.S. (63.9\%) (European Public Real Estate Association, 2016 and Ntuli and Akinsomi (2016)). All these markets, except Belgium, are also defined as established and mature markets based on 9 different criteria in EY Global perspectives: 2016 REIT report. This makes the present study one of the most comprehensive analysis of the impact of major macroeconomic and policy announcements on the global REIT markets.

${ }^{2}$ In this regard, Krueger and Kuttner (1996) find that the Federal funds futures rate is an unbiased predictor and an efficient measure of the Federal funds rate. In addition, Gürkaynak et al. (2012) show the superiority of the Federal funds futures price among different market-based measures of monetary policy expectations.
} 
with it being considered as a natural market-based proxy for the otherwise unobserved market expectations (Kishor and Marfatia 2013). The main presumption behind using the futures price is that all the future expectations about interest rates would be embedded in the futures price at the current point in time (as with macroeconomic news discussed above), and any change in the futures rate post-FOMC meeting is because the announced rate change (or no change) was unexpected before the FOMC meeting, thus leading to an impact on the returns on financial assets, like that of REITs.

In light of the above reasons, it is not surprising that there exists a huge international literature that has looked at the impact of domestic as well as U.S. monetary policy and macroeconomic news surprises on bonds, commodity, currency and equity markets (see, for example, Kishor and Marfatia (2013); Cakan et al. (2015); Caporale et al. (2016); Scotti (2016) for detailed literature reviews in this regard). Surprisingly, the analysis on REIT markets, in spite of their growing worldwide importance has been limited primarily to the U.S. and also only to monetary policy surprises, as observed in the works of Bredin et al. (2007, 2011) and Claus et al. (2014). While Xu and Yang (2011) and Claus et al. (2014) are the only studies to have shown the significant impact of U.S. monetary policy surprises on international REIT markets; Kroencke et al. (2016) looked at the role of U.S. and U.K. macroeconomic news surprises in affecting REIT returns in these two countries.

The above-mentioned studies on the high-frequency response of REIT returns to monetary and macroeconomic news surprises use a fixed-coefficient approach, though Kroencke et al. (2016) does look at some pre-determined sub-samples. The underlying assumption is that the response of REIT returns to shocks remains unchanged over time. This is in contrast to the anecdotal and formal evidence which suggests that the response of financial market returns varies over time (Bekaert and Harvey 1995; Campbell et al. 1997; Bernanke and Kuttner 2005; Andersen et al. 2007; Kishor and Marfatia 2013). Moreover, studies find that factors that explain the movements REIT market differs greatly in the turbulent times as compared to normal periods (Ghysels et al. 2013; Akinsomi et al. 2016a). These factors, like uncertainty, are dynamic in nature. Hence, if the factors that explain REIT dynamics are not constant over time then using the fixed-coefficient model to assess the response of REITs would be inappropriate.

Against this backdrop, we for the first-time contribute to the existing literature by taking into account the possible time-variation in the behavior of domestic and foreign REIT markets due to the U.S. surprise shocks. We analyze the monetary policy surprise of the Federal Reserve (Fed) as well as U.S. inflation and unemployment surprises. In the process of analyzing the importance of monetary and macroeconomic news surprise, we also add to the literature on drivers of the REIT market. ${ }^{3}$ As in the pioneering work of Cooley and Prescott (1976), the time-variation is modeled as a driftless random walk and is estimated using maximum likelihood via the Kalman filter. We consider

\footnotetext{
${ }^{3}$ See, for example, Ghysels et al. (2013) and Akinsomi et al. (2016a) for detailed reviews in this regard.
} 
this approach as an appealing and flexible way of uncovering changes in the responsiveness of REIT returns to U.S. macroeconomic news and monetary policy shocks. Our time-varying approach is important since it allows us to detect periods in which the U.S. and international REIT markets are less sensitive towards monetary and macroeconomic news. This would provide insights in the periods where the fundamental factors associated with the U.S. economy are less important for pricing, possibly suggesting that the behavioral variables could be playing a role in pricing REITs.

Previewing our results, we observe that the impact of U.S. monetary policy and economic surprises on the global REIT markets has not been constant over time. There is evidence of significant structural breaks in the impact of all the measures of surprise with a more pronounced impact in the 2000s as compared to the periods prior to that. This is particularly true in case of inflation surprises impacting global REIT stocks. Furthermore, there is convincing evidence which suggests that the response of global REIT to U.S. shocks varies significantly both across time as well as across countries. In the case of Australia and Canada, we find that the Feds policy actions are increasingly watched by the real estate markets in these two countries. The impact of an unexpected increase in the inflation rates in the U.S. on global REITs is largely negative, except in the case of Netherlands and New Zealand. Also, the time-varying response pattern of REIT stocks in Belgium, France, and Netherlands to the U.S. unemployment surprises is wider than the response in other parts of the world.

The remainder of the paper is organized as follows: Section 2 presents a brief review of the related literature. Section 3 lays out the basics of the time-varying methodology and the data used. Section 4 discusses the results and finally and Section 5 concludes.

\section{Literature Review}

Macroeconomic news announcements are among the most important risk factors for financial markets because the state of the economy is a major candidate for such a source of non-diversifiable risk. The cause of stock market fluctuations have been studied by researchers (Chen et al. 1986; Campbell and Shiller 1988; Fama and French 1988). For example, Ederington and Lee (1993) find a significant effect of regularly scheduled US macroeconomic announcements on the volatility of the US treasury and foreign exchange futures.

There are many examples of empirical evidence in support of the non-domestic macroeconomic news affect the domestic financial markets. Examining the reaction of asset prices to macroeconomic announcements in Hungary, Czech Republic and Poland using intraday data, Hanousek et al. (2009) find that Czech stock market is impacted more by the U.S. macroeconomic announcements than by EU macroeconomic announcements. More, the existing international literature that has looked at the impact of domestic as well as U.S. monetary policy and macroeconomic news sur- 
prises on bonds, commodity, currency and equity markets (see, for example, Kishor and Marfatia (2013); Cakan et al. (2015); Caporale et al. (2016); Scotti (2016) for detailed literature reviews in this regard).

The effect of macroeconomic news on developed economies, especially the U.S. on REITs are not well studied. As the first author to attempt to examine the U.S. REITs response to macroeconomic news, Bredin et al. (2011) use unexpected changes in U.S. monetary policy by futures of the policy rate. Their findings support a negative response of REIT returns to a surprise change in the policy rate and they also find monetary policy surprises regularly have an impact on REIT returns and that the dividend channel is a driving force behind this influence. On the other hand, by analyzing the real estate returns of US REITs and a set of possible predictors for the period January 1991 to September 2013, Akinsomi et al. (2016a) employ several forecasting models to test for REITs predictability under a flexible framework that captures parameter instability. The empirical results indicate that the good predictors of REITs returns vary over time and over the forecast horizons.

Yunus (2009) explores the convergence of international REITs. They find that over the 19902007 period, the property markets of Australia, Hong Kong, Japan, the U.K. and the U.S. are co-integrated, with the lead role of the U.S. and Japan in maintaining the long-run relationship between these countries. If the international REIT are cointegrated it becomes necessary to explore the extent to which the events in the U.S. impact the international REITs, which is one of the main objective of the paper. This issue gains further relevance given Yunus (2009) finds that from the perspective of the U.S. investor the markets of the Netherlands and France provide the greater diversification benefits.

Bredin et al. (2007) investigate the influence of changes in U.K. monetary policy on U.K. stock returns and the possible reasons behind such a response by conducting an event study. They evaluate the impact of unexpected changes in monetary policy on aggregate and sectoral stock returns. The decomposition of unexpected changes in the policy rate is based on futures markets data. Using a variance decomposition, they characterize the channels behind the response of stock returns to monetary policy surprises. Their results indicate that the monetary policy shock leads to a persistent negative response in terms of future excess returns for a number of sectors.

By examining the responses of U.S. asset markets to domestic monetary policy shocks during the 1996-2016 period, Claus et al. (2014) examine the usefulness of shadow short rates as a metric across conventional and unconventional monetary policy environments. Their results show that asset market responses to policy shocks have been larger since short term nominal interest rates reached the zero lower bound and the increased responses of asset markets in the unconventional period seem due to larger policy shocks rather than a change to their transmission.

While $\mathrm{Xu}$ and Yang (2011) examines how the U.S. monetary policy surprises impact the mortgage rates in the nation and across five regions from 1990 to 2008, their analyses depend on 
regression based on bootstrapping which show that surprises in the target federal funds rate (the target factor) have a significantly positive impact on the 1-year adjustable-rate mortgage (ARM) rate within the week of the FOMC announcements and the positive impact lasts up to one week after the announcements. Furthermore, the responses of mortgage rates are asymmetric and affected by the size of monetary policy surprises, the stage of the business cycle and whether the monetary policy is tightening or loosening. The cross-region variations are mainly correlated with the regional housing market conditions, such as home vacancy and rental vacancy rates.

The above-mentioned studies on the high-frequency response of REIT returns to monetary and macroeconomic news surprises use a fixed-coefficient approach, though Kroencke et al. (2016) does look at some pre-determined sub-samples. Analyzing the sensitivity of listed real estate returns with respect to the surprise component of a wide range of macroeconomic data announcements by using time varying parameters, Kroencke et al. (2016) examine the excess returns on a daily basis analyze the listed real estate excess returns on a daily-frequency of the U.S and U.K. They cover the surprises of U.S. news of measures of capacity utilization, consumer confidence index, consumer price index, GDP, manufacturing, leading index, new home sales, non-farm payrolls, retail sales, and the unemployment rate. They find that real estate returns are much less exposed to the risk of macroeconomic announcement days than stocks and bonds in the U.S. In the U.K., they do not to find statistically significant differences of the daily excess returns for stocks, bonds, or real estate, but mostly surprise components of retail sales and unemployment rate are statistically significant linked with real estate returns. These impacts changed after 2009 and their signs are different in the U.S. and the U.K.

\section{Methodology and Data}

\subsection{Methodology}

This section presents the method of computing monetary policy and macroeconomic surprises, and how these surprises impact the REIT stock returns.

\section{Monetary Policy and Macroeconomic Surprises}

In order to uncover the impact of U.S. policy and economic surprises on the REITs across the world, it is important to first measure the extent of surprises. This is important because financial markets react only to the news component of the announcements. In other words, any expected changes of the announcements/releases would have no impact on the global REIT stock returns,

and only the unexpected surprises would move the markets. To measure the Federal Reserves' policy surprises, we adopt the widely used methodology proposed by Kuttner (2001). This method 
takes the information contained in the Fed funds futures market to extract in the monetary policy shocks. The Fed funds futures rate is found to be an unbiased predictor of the future policy actions by the Federal Reserve (Krueger and Kuttner 1996; Gürkaynak et al. 2012). In particular,

$$
\operatorname{mpsurp}_{\tau}=\frac{m_{s}}{m_{s}-\tau}\left(f_{s, \tau}^{0}-f_{s, \tau-1}^{0}\right)
$$

where, $\operatorname{mpsurp}_{\tau}^{u}$ is the monetary policy surprise, $m_{s}$ is the number of days in the month $s, f_{s, \tau}^{0}$ is the current month futures rate on day $\tau$ of the month $s$ and $f_{s, \tau-1}^{0}$ is the current month futures rate on day $\tau-1$. All other adjustments particularly related to the end of the month effects are made in accordance with Kuttner (2001). One of the key advantages of such a measure to gauge policy surprises is that it is free of model selection and the generated regressors problem. Among the variety of market-based measures of monetary policy expectations, the Fed funds futures rate is found to dominate all other instruments in predicting the future path of monetary policy at horizons out over several months (Gürkaynak et al. 2012). ${ }^{4}$ Since these surprises are extracted from financial futures market they provide a far superior measure of market expectations of future policy actions. Several papers discuss the merits of this widely used measure of monetary policy surprises (Kuttner 2001; Bernanke and Kuttner 2005; Hausman and Wongswan 2011). In this paper, we follow the literature and use the most liquid spot-month contracts for the purpose of extracting out the monetary policy surprises at each FOMC meeting.

In order to compute the macroeconomic surprise emerging out of inflation and unemployment announcements, we again use the information contained in the financial markets, i.e., the market expectations of the announcement at that date. The market expectations of the announcements are measured by Bloomberg forecasts. Let $F_{i}$ denote the median value of the forecast of the variable $i$ derived from the Bloomberg forecast survey and $A_{i}$ the released value of announcement $i$, namely, inflation rate and unemployment rate. We measure the surprise in announcement $i$ as:

$$
\text { macrosurp }_{i}=A_{i}-F_{i}\left(A_{t}\right)
$$

Following Balduzzi et al. (2001), we compute the unexpected components of the announcements as the standardized differences between the actual announcement values and their median expected values. For ease of comparison across the monetary policy and two macroeconomic surprises, we standardize the surprises by dividing them by their standard deviation across all observations. The

\footnotetext{
${ }^{4}$ Alternative measures used includes term Eurodollar interest rate (Cochrane and Piazzesi 2002), Eurodollar futures interest rate (Rigobon and Sack 2004), three-month Sterling LIBOR futures rate in case of the U.K. monetary policy surprise (Bredin et al. 2007).
} 
standardized measure of the surprises can, therefore, be expressed as

$$
\operatorname{surp}_{i}=E_{i} / \sigma_{i}
$$

where $E_{i}$ represents the mpsurp derived in equation 1 and macrosurp $_{i}$ computed in equation 2.

The time-varying parameter model

Given the anecdotal and formal evidence which suggests the possibility of substantial insatiability in the response of financial market returns over time (Bekaert and Harvey 1995; Campbell et al. 1997; Bernanke and Kuttner 2005; Andersen et al. 2007; Kishor and Marfatia 2013), we adopt a time-varying parameter (TVP) framework. This framework provides a flexible way to uncover the impact of monetary policy and macroeconomic surprises on the REIT returns across the world. To take advantage of this framework, we cast the TVP model into the standard state-space form. The state-space specification involves two equations: a measurement equation describing the relation between observed variables (data) and unobserved state vector (time-varying coefficients) and a transition equation which describes the dynamics of the unobserved state vector.

In the present context, the measurement equation of the state-space model shows the unobserved time-varying response of REIT returns to the U.S. monetary policy and macroeconomic surprises. The measurement equation is then represented by equation $4 \mathrm{a}$ which has a straight forward state-space representation given by equation $4 \mathrm{~b}$.

$$
\begin{gathered}
R_{t}=X_{t} \theta_{t}+e_{t} \quad \text { where, } e_{t} \sim N\left(0, \sigma_{e}\right) \\
R_{t}=\left[\begin{array}{ll}
c & \text { surp }
\end{array}\right]\left[\begin{array}{c}
\alpha_{t} \\
\beta_{t}
\end{array}\right]+e_{t}
\end{gathered}
$$

Here, $R_{t}$ represents the REIT stock returns, $X_{t}$ is a vector of exogenous variables which includes a constant $(c)$ and one of the surprises $(\operatorname{surp}),{ }^{5}$ and $\theta_{t}$ is a vector capturing the corresponding unobserved time-varying parameters $\left(\alpha_{t}\right.$ and $\left.\beta_{t}\right)$ of the model. Our parameter of interest is the coefficient $\beta_{t}$ which captures the time-varying impact of U.S. news announcements on REIT stock returns.

The next step is to specify the transition equation of the state-space system. Following the pioneering work of Cooley and Prescott (1976) the time variation is modeled as a driftless random walk process. This allows for the impact of the news to evolve gradually over time. The transition equation and its state-space form are then represented as follows:

$$
\theta_{t}=F \theta_{t-1}+v_{t} \quad \text { where, } v_{t} \sim N(0, Q)
$$

\footnotetext{
${ }^{5}$ We estimate the TVP model for each surprise separately and hence the subscript $i$ is dropped merely for ease of presentation.
} 


$$
\left[\begin{array}{l}
\alpha_{t} \\
\beta_{t}
\end{array}\right]=\left[\begin{array}{ll}
1 & 0 \\
0 & 1
\end{array}\right]\left[\begin{array}{l}
\alpha_{t-1} \\
\beta_{t-1}
\end{array}\right]+\left[\begin{array}{l}
v_{1 t} \\
v_{2 t}
\end{array}\right]
$$

where, $Q$ represents the variance-covariance matrix of two uncorrelated disturbance terms $v_{1 t}$ and

$v_{2 t}$. This transition equation describes the time dynamics of the unobserved state vector $\theta_{t}$ which contains the time-varying parameters $\left(\alpha_{t}\right.$ and $\beta_{t}$ ). The Kalman filter is applied to the above statespace model and the parameters are estimated using maximum likelihood.

\section{Modeling Approach}

The impact of the economic and policy surprise on the REIT stocks across time is analyzed within the event study approach. Researchers have often adopted the event study methodology using highfrequency data in order to control for the problem of endogeneity and the possible problems due to the joint response of the economic shocks and the stock markets to new information (Bernanke and Kuttner 2005). Following the popular conventional Cook and Hahn (1989) style analysis, we estimate the impact of the monetary policy and economic surprises on the REITs across the world.

The event of interest in our analysis is the FOMC meetings and the announcements of inflation and unemployment rate. Following Bernanke and Kuttner (2005) and Hausman and Wongswan (2011), we take one day as the size of the event window. While few studies use a smaller window and use intra-day data, the selection of window size has several merits. A one-day window is more likely to capture the true impact of US shocks on the REIT returns, rather than the kneejerk reactions that may be witnessed in a few minutes around the announcements. This ensures evenness of comparison across markets some of which may be relatively slower at incorporating the arrival of new information. Moreover, as long as the confounding events and other marketwide news, which can arguably influence REIT returns, do not occur at systematic occurrence with the announcements, a one-day window is most appropriate in the present context. This modeling strategy is also supported by popular event studies like Bernanke and Kuttner (2005) and Hausman and Wongswan (2011).

Alternatively, Ooi et al. (2011) have used a wider window of more than one day to evaluate the wealth effects of property acquisition announcements on the REITs in Singapore and Japan. However, we chose the one-day window because it is more likely to address endogenity problem, reduces the risks of contaminating the effects of other events in a wider widow, the advanced nature of financial markets, and the forward-looking nature of announcements evaluated. Moreover, as a robustness check, we also use a 3-day average return window and find not qualitative change in the main results of the paper. ${ }^{6}$

Due to the difference in the time zones and the closing time of stock markets across countries,

\footnotetext{
${ }^{6}$ These results are not included in the paper to maintain brevity but are available upon request.
} 
it is important to carefully align the dates to study the impact of the event. In the case of European and Asia Pacific markets, we take the REIT returns of the following day of the corresponding announcement dates. However, the impact on REIT returns on the REITs in the U.S. and Canada occurs on the same day. Hence, in these cases, we take the announcements dates as the event dates to measure the impact on REIT stock returns.

\subsection{Data}

We have announcements of the U.S. macroeconomic variables from Jan 11, 1994 to March 17, 2016 and for the Federal Reserves' policy surprises from Feb 11, 1994 to June 25, 2008. Using the information from the federal funds futures rate after 2008 would lead to incorrect inference because the federal funds rate, and hence the future rate, is at near zero level in the post-2008 period. Due to this constraint of zero lower bound on interest rates, the monetary policy surprises computed from the federal funds futures rate are for the 1994-2008 period. This leads to the total sample of 257 announcements for the U.S. consumer price index and the unemployment rate, respectively, and 116 announcements for the Federal Reserves' policy changes. The data set on global REIT returns is sourced from Datastream and includes 5778 daily observations of S\&P REIT price indices of each country in US dollars. The response of REIT returns to surprises on the event dates are estimated for Australia, Belgium, Canada, France, Japan, Netherlands, New Zealand, and the U.S.

This selection of countries is mainly driven by several consideration. First, the eight countries included in the paper constitute $88.3 \%$ of the global REIT index based on market capitalization which includes Australia (8.28\%), Canada (3.14\%), France (1.85\%), Japan (5.93\%), Netherlands (3.05\%), and U.S. (63.9\%) (European Public Real Estate Association, 2016 and Ntuli and Akinsomi (2016)). Thus, the selected countries constitute the top 10 REITs market with the exclusion of the U.K, Hong Kong, Singapore but inclusion of Belgium and New Zealand (Ntuli and Akinsomi 2016). Moreover, all the countries included in the study are defined as established and mature markets based on 9 different criteria which include capital flows, financial reporting, corporate governance, risk management, regulatory environment, cross-border issues, transaction activity, financing, and property specifics (EY Global perspectives: 2016 REIT report). The only exception is Belgium which is defined as an emerging market based on the aforementioned different criteria. These parameters highlight that the markets analyzed in this study capture more than two thirds of the international developed REIT market's movements. Third, there are binding constraints between the objective of including several announcements and availability the data. In light of all these facts, the present study provides one of the most comprehensive analysis of the impact of major macroeconomic and policy announcements on the global REIT markets in the stated sample period.

The choice of these countries, besides the U.S., are motivated by the availability of long-span 
data covering over two decades, which in turn, would allow us to analyze the evolution of the response of these markets to U.S. macroeconomic and monetary policy news surprises, as these REITs markets have developed over time from their point of being under operation. This will provide an indication as to whether the impact of U.S. macroeconomic news surprises have been conditional on the different stages of development of these markets along with that of the U.S. Also, long data spans are particularly advantageous inn estimating time-varying parameter models.

We obtain the macroeconomic announcements related to the U.S. inflation and unemployment rates from the websites of the Bureau of Economic Analysis (BEA) and the Bureau of Labor Statistics (BLS), respectively. ${ }^{7}$ Data on market expectations of the unemployment and inflation rates for the period between 1994 to 2005 are obtained from the Money Market Survey. For the remaining sample period from 2005 to 2016, we obtain these data from the Bloomberg Survey extracted from the Bloomberg terminal. The monetary policy surprise are computed from the 30-day Federal funds futures market contracts that most closely track the effective overnight Federal funds rate for a specific month. ${ }^{8}$

A preliminary overview of summary statistics of the three measures of news is presented in table 1 . The average monetary policy surprise is at -0.93 suggesting that the Federal Reserve, on average, has surprised markets by cutting the interest rate more aggressively than what the market expected. This also suggests that the Fed has taken aggressive steps to combat recession but has been overall cautious in increasing the rates after the recessions. The surprise for inflation and unemployment is also negative on an average. This means that the actual outcome of these two macroeconomic variables has been, on an average, lower than the market expectations.

\section{Results}

\subsection{Fixed Coefficient and Structural Break}

The OLS estimates for the full sample are presented in the table 2 columns 2-3. The evidence from the full sample estimate shows that the shocks from the U.S. do not statistically impact the REITs across the world. These estimates raise a very fundamental question. Is it the case that the U.S. news do not impact global markets or is it the case that there are hidden dynamics involved in the impact of the U.S. news which is not revealed by a simple OLS? To put this differently, does the impact of the U.S. policy and economic shocks across the global REITs remain constant across time as the fixed coefficient OLS framework assume? Most likely no. There is convincing anecdotal

\footnotetext{
${ }^{7}$ Inflation and unemployment rate announcements are released at 8:30 am U.S. Eastern time.

${ }^{8}$ Federal funds futures prices are expressed as 100 minus the expected average effective Federal funds rate for the delivery month. For example, if a November contract has a price of 97.75 , it reflects an anticipated average rate of 2.25 percent for that month. The Federal funds futures contract rate has been provided by Kenneth N. Kuttner.
} 
as well as formal evidence which suggests the shocks that emerge from the U.S. impact the global REITs (Yunus 2009; Xu and Yang 2011; Liu et al. 2012; Lu et al. 2013). Also, the pace of integration of the global markets is one of the lead factors that drive the impact of the U.S. shocks on the global markets. Moreover, Bekaert and Harvey (1995) show that there is a significant time variation in the world market integration. In light of these evidence it would be incorrect to conclude that the U.S. shocks do not impact global REITs, rather it is most likely that the impact is not constant across time.

The literature suggests several methods to model the time-varying impact of a variable. To begin with, we adopt the most basic and preliminary test of structural break suggested by Bai and Perron (2003). Table 2 (columns 4-8) presents the estimates along with the break dates from Bai and Perron (2003) multiple structural break model. The evidence suggests that once we allow for breaks in the model we find that the shocks in the U.S. do have a statistically significant impact on the global REITs. This highlights the main premise of the paper that there is a time-varying impact of the U.S. policy and economic shocks on the global REITs.

The evidence also suggests that the impact of U.S. shocks is more pronounced over the last decade as compared to the period before the 2000s. The results show that among the three shocks, the inflation surprises has the most significant impact on the REIT returns across the world. One of the explanations for a stronger impact in the post-2000 could possibly be the increased interconnectedness of the global real and financial economy (Yilmaz 2010; Diebold and Yilmaz 2013, 2015).

The results in panel A suggest that a one percent in expected increase in the Federal Funds rate leads to a 0.47 percent decrease in the REIT stock returns in the U.S. in the post-2005 period. The monetary policy shocks not only impact the U.S. REITs but also impact Canadian and Japanese REIT stocks. In fact, the impact on Canadian REITs of Fed's policy shocks is even stronger at 0.65 percent as compared to the U.S..

Panels $\mathrm{B}$ and $\mathrm{C}$ of table 2 provide the results for the impact of inflation and unemployment surprise on the REIT returns across the world. Evidence suggests that the information contained in the inflation news holds a greater potential to move the global REIT stocks as compared to the unexpected movements in the U.S. unemployment rates. The intuition for the relatively high importance of inflation surprises is because REITs are known to be sensitive to inflation (Ghysels et al. 2012; Akinsomi et al. 2016a). However, it could also be suggesting the impact of unemployment and monetary policy in the future. With forward-looking agents, this could lead to a bigger impact on the markets than the other two shocks. Evidence also suggests that the impact of inflation surprises on the global REIT stocks has been mixed. This is consistent with Chang (2017), where it is found that REIT index inflation-hedging ability is not fixed over time.

Comparing the two sample periods in panel $\mathrm{B}$, we also find that the break dates are mostly 
around the time of the recent financial crisis. This reflects the changing relationships between inflation shocks and REIT returns due to the severity of the crisis. This is true not just in the U.S. but across the global REIT stocks. We find that majority of global real estate markets are affected by the inflation surprises in the U.S.. In case of the U.S., the impact of inflation surprise on the U.S. REIT is found to be nearly three times stronger in the post-crisis period as compared to the period before 2008. An unexpected increase in the inflation rate by one percent in a pre-crisis period lead to a 0.23 percent increase in the REIT returns in the U.S.. However, in the post-crisis period the sign of the coefficient reversed with a statistically significant impact of 0.59 percent. This shows that the U.S. real estate markets viewed inflation news more as a signal of the future state of the economy. In contrast, after the recent financial crisis the real estate started paying more attention to the more fundamental impact of inflation news. This may possibly have to do with the links of the Fed's policy stance of lifting the zero rates and the deflationary pressures in the recent past.

\subsection{TVP Model}

Figure 1 reveals the time-varying impact of the U.S. monetary policy surprises on the global REITs. The time-varying impact in each plot is presented by a solid line and is measured on the left scale. Also, the dotted line measured on the right scale captures the market capitalization to GDP ratio which likely explains that time variation and is discussed in the next section.

Clearly, the impact of an unexpected change in the Fed's policy rate has a significant timevarying impact (solid line) on the REIT stocks across the world. This is particularly true in the case of Australia, Canada, and New Zealand. Both in Australia and Canada, we find that the Fed's policy actions are increasingly watched by the real estate markets in these two countries. Notice that the impact of U.S. monetary policy surprise is both positive like in the case of Australia, New Zealand, the U.S. as well as negative like in the case of Canada and Netherlands. Thus, the impact of an unexpected hike (cut) in the Federal funds rate causes the REITs in the U.S. and Australia to go up (down) whereas, it decreases (increases) Canadian REIT returns. This suggests that the U.S. and Australian real estate markets view the Fed's policy actions as more of a signal. A rate hike signals a strong economy and which boosts the real estate markets in the U.S. and Australia. In contrast, an interest rate hike in the U.S. together with higher interest rate elsewhere leads to higher borrowing costs, lowering the housing demand. This causes a stress on house prices, thus dampening the REIT stock returns. This phenomenon holds true in the case of Canada's real estate markets.

Even though the impact in the U.S. of the Fed's policy actions does vary significantly across time, the impact in the 2000-2005 period has been rather steady. Similar is the reaction of the European REIT stocks to the U.S. monetary policy surprises. One of the likely reasons for a rather

steady path of impact is because around this period most policy actions were expected by the 
markets which coincided with a booming housing market in the run-up to the crisis.

Figure 2 reveals the time-varying impact of the U.S. inflation surprises on the global REITs. Several key insights emerge from these results. First, the impact of the U.S. inflation news beyond what the market expected is largely negative in all the countries, except Netherlands and New Zealand. This is most likely explained by the inflation hedge motives of the international investors (Hong and Lee 2013; Chang 2017). Second, there is a significant time variation in the response of the global REITs to unexpected news about inflation in the U.S.. This highlights one of the main contributions of the paper. Third, in the U.S. the impact of inflation surprise was decreasing turning from positive to negative for the 1998-2000 period, steadily increased during the housing boom witnessed in the early 2000s, but has decreased or remained constant since the onset of the crisis. The response pattern of REIT stocks in Australia and Canada is largely similar. One of the forces that drive REIT stock investments is the investor's motives to hedge against inflation. One of the key explanations to the mixed response of global REIT stocks to inflation shocks is the changing nature inflation-hedging ability of REIT index. These results also support existing evidence found in Hong and Lee (2013).

Figure 3 presents the time-varying impact of the U.S. unemployment surprises on the global REITs. One of the key features that emerges from all the plots is that there is a remarkable shift in the impact of unemployment news on the global REIT in the post-2008 crisis period. This is particularly true in the case of Australia, Belgium, Canada, and the U.S.. In the 1995-2005 period, actual unemployment rate beyond market expectations caused a boom in the real estate markets in these markets. In the case of Australia, Belgium, and Canada this shows the international portfolio reshuffling effects. An unexpectedly higher (lower) unemployment rate in the U.S., for example, made the international investor reshuffle their international portfolios away from (into) the U.S., which in turn leads into a positive (negative) REIT returns in the international REIT returns. However, this reversed in the post-crisis period and the sign of REIT responses turned negative in most cases. That is, in the post-2008 period, an unexpected increase (decrease) in unemployment rate led to a drop (increase) in the REIT returns across the globe. This reflects the catastrophic effects of recent financial crisis where there was not many places for the international investors to hide. Further, most time variation is found in the response of the three European countries in the sample namely, Belgium, France, and Netherlands.

It is important to note that the international effect of U.S. macroeconomic surprises could broadly be both positive or negative. A negative domestic macroeconomic and monetary policy surprises could result in either an increase or decrease in the global REIT returns. An increase is possible if investors decide to move funds out of the U.S. real estate market in the wake of bad news in terms of increase in inflation, unemployment and monetary tightening beyond what the markets expected. At the same time, it is also possible that given the global dominance of the U.S. economy, 
investors might feel that with a bad news of a slowing U.S. economy could also potentially slowdown the global markets including the REIT sector, and this makes investors move funds into safe havens like gold. Further, intuition for a broadly stronger impact of the U.S. news in the 2000-2005 period is that there is increased interconnectedness of the global real and financial economy (Yilmaz 2010; Diebold and Yilmaz 2013, 2015), but these interconnections has weakened due to the slowing down of investment in the real estate sector in the aftermath of global financial crisis (Akinsomi et al. 2016a).

Even while the magnitude of impact is time-varying, there is evidence of increased role of the U.S. in the global REIT markets. This is particularly true in the case of REIT market of Australia, Japan, Netherlands, and France, at least in the pre-crisis period. This collaborates with the existing evidence where Yunus (2009) finds that the property markets of Australia, Hong Kong, Japan, the U.K., and the U.S. are cointegrated, with the U.S. and Japan being the sources of the common trends, suggesting that the two larger property markets lead the five cointegrated markets toward the long-run equilibrium relationships. Our results collaborates with these existing findings, which in turn further support the choice of countries in the study.

It also tends to suggest that as the markets develop, they also possibly get more integrated or comparable with the U.S. in terms of investors diversifying their portfolios with international REITs, consequently making the impact of US shocks became more important. Given that we provide preliminary, and perhaps indirect evidence of integration of international REITs markets, as part of future research, it would be interesting to conduct a full-fledged time-varying analysis of integration and the factors driving the process using newly developed econometric frameworks (See, for example, Ji and Guo (2015); Ji and Fan (2016)).

Overall, we find that there is a significant variation across time in the impact of U.S. macroeconomic and monetary policy surprises on global REIT returns. The time-variations reveal the importance of significant structural changes witnessed in the global economic environment in the last three decades. Evidence also suggests that a bad macroeconomic and monetary policy news could result in either increase or decrease in REIT returns of the global economy. The innovative approach of the paper is able to bring forth the interesting interplay of the international portfolio reshuffling effects on one hand and the effects of U.S. dominance in the international financial markets.

\subsection{What Explains the Time-Varying Impact?}

The natural issue that emerges from these findings is that to what extent are these time variations explained by the relative size of the stock market? This question is important because if the stock market of the country has deep penetration into the economy, then it is likely to be very well 
developed and more integrated with the international economy. Consequently, in these cases the REIT stock returns are more likely to be affected by the international financial market conditions. Since the U.S. is at the center of the international financial system, it would be interesting to explore the extent to which the time-varying patterns are connected with stock market penetration of the country. At the same time, it is possible to contemplate that the nature of movement in REITs due to the U.S. shocks has implications on the international portfolio reshuffling, and consequently on the stock market capitalization of the country. In either scenarios, it would be interesting to explore the possible connections of country's stock market penetration and its REIT's time-varying response patterns to the U.S. shocks.

To measure the relative role of the stock markets in the economy, we use the stock market capitalization to GDP ratio. The data for the stock market capitalization to GDP ratio is obtained from the world bank database. The stock market capitalization to GDP ratio is presented as a dotted line (measured on the right scale) in each of the plots that present the time-varying effects of the U.S. news shocks on the global REITs. This will better reflect the connections, if any, between the extent of stock market penetration and the time-varying response of REIT stock returns.

We gain following insights from assessing the connections between the time-varying impact of the U.S. monetary policy surprise and stock market capitalization ratio (fig. 1a-1h). Broadly, we find that the time-varying impact can be explained by the market capitalization ratio. This is relatively more explicit in the case of Australia (fig. 1a), Canada (fig. 1c), and New Zealand (fig. 1g). More importantly, this relationship of the market capitalization ratio is not always positive throughout the 1995-2005 period. For example, in the case of the U.S., we find that in the 1995-1999 period the market capitalization ratio steadily increased from 90 percent of GDP to 153 percent, whereas the impact of Fed's policy surprise on the REIT stock returns was largely declining in the same period. This implies that in the 1995-1999 period the Fed's unexpected aggressive expansionary policy fueled overall stock markets, including the REITs, and its impact was largely on a declining path.

Exploring the connections between the market capitalization ratio and the time-varying response of international REITs to U.S. inflation news also provides interesting insights. Evidence from figures 2a-2h suggests that in the case of France (fig. 2d), Japan (fig. 2e), and Netherlands (fig. 2f) there is a striking overlap of the capitalization ratio pattern with the time-varying response pattern of REITs. This indicates the higher (lower) the penetration of the stock markets in these economies, the greater (smaller) is the sensitivity of the REIT stock returns to the U.S. inflation news.

In figures $3 \mathrm{a}-3 \mathrm{~h}$, we study the connections between market capitalization and the REIT response patterns to U.S. economic conditions as measured by the unemployment rate. Here again, we find that the capitalization ratio closely explains the time-varying response of REITs to the U.S. 
unemployment news. This is particularly pronounced in the case of Belgium (fig. 3b), Netherlands (fig. 3f), and the U.S. (fig. 3h). It is also interesting to find that in many cases the market capitalization ratio changes in a particular direction and this is followed by similar response pattern amongst REIT returns in the subsequent periods. This suggests that there is both lead and lag relationship of the capitalization ratio. In other words, a slowdown in the stock market of a particular country relative to its economic growth is in some sense a harbinger of the sensitivity of REIT stock returns to the U.S. economic situation, that is, unexpected movements in the U.S. unemployment rate.

When compared to the past literature, as discussed in detail in Xu and Yang (2011), explanations of the varied impact of U.S. monetary policy surprises on international REIT markets have been primarily tied to financial and economic integration. We, however, highlight the importance of stock market penetration into the economy, as the factor driving the response to not only monetary policy surprises, but also unemployment and inflation news surprises. This is because higher stock market capitalization is a general indicator of the fact that equity markets, and hence REITs, are developed and more integrated with the international economy. Naturally, this leads the REITs to be affected by the international financial market conditions, which in our case, corresponds to U.S. monetary policy and macroeconomic news surprises.

Another way to understand the time-varying patterns is to look at the cross-sectional behavior of the responses. Table 3 presents a simple correlation coefficient between the time-varying responses across the countries. This will provide us insights into the extent to which the impact on the REITs across the globe is connected. Evidence from panel A of Table 3 reveals that the time-varying impact of monetary policy surprise on REIT returns of Australia, Belgium, Canada, and France are highly correlated (the correlation is greater than 0.8). This is in contrast to the time-varying impact of inflation and unemployment surprise. The international REITs time-varying response to inflation (Panel B) and unemployment (Panel C) surprise is much more varied as compared to the monetary policy surprises' time-varying responses. One exception to this is the case of Canada. The correlation between the U.S. and Canada's response to monetary policy shocks is 0.02 , whereas the correlation of time-varying response to inflation and unemployment shocks is 0.66 and 0.75 , respectively. Overall, the impact pattern of the Fed's announcements is largely correlated in the international real estate markets. However, the response to inflation and unemployment news is relatively more unique.

\section{Conclusion}

This paper uses a flexible time-varying parameter model to unveil the dynamic impact of the U.S. monetary policy and economic developments on the international REIT stocks. The evidence clearly suggests that there are significant structural changes in the way the U.S. developments impact 
international real estate markets. In particular, there is wide variation across time in the response of the REIT stocks to the unexpected movement in the U.S. monetary policy, inflation, and employment conditions. In the case of the Fed's policy shocks, the impact on the international REITs is driven by the signaling effect as well as through the classic asset price channel of the monetary policy transmission of shocks. The adopted framework precisely traces the relative role of these two channels over time. In the case of the unexpected movements in the U.S. inflationary conditions, evidence suggests that the inflation-hedging ability of REIT index is not constant across time. We also find wide time variation in the response of REIT stock to unexpected changes in the U.S. employment conditions. Further, there is strong evidence of connections between the extent of stock market penetration in the economy and the time-varying response patterns of the international REIT stocks.

Our results have important implications for academics, investors, and policy makers. For the academicians, our results tend to highlight the fact that the semi-strong efficient market hypothesis seems to hold for the international REITs markets considered relative to U.S. macroeconomic news and monetary policy surprises. This is because, we find that the unexpected difference between the predicted and the announced data of the U.S. (i.e., the surprise component) matters in the pricing of international and domestic REITs market. Given our findings that impact on the REITs across the globe is more connected in case of monetary policy surprises than in cases of inflation and unemployment surprises tend to suggest that diversification opportunities for investors are weaker following a monetary policy shock, when compared to macroeconomic shocks. Finally, as far as the policymaker is concerned, in the wake of the recent financial crisis and the associated role of real estate markets in causing it, makes predicting the path of these markets of paramount importance. Recall that, REITs constitute a very good proxy for the movements of the real estate market at high-frequency since REITs shares trade as common stocks. The fact that information of U.S. monetary policy and macroeconomic news surprises have a role to play as predictors of both U.S. and international REITs, it provides tremendous value to the policymaker in forecasting the future path of real estate markets and the economy in general, given that real estate markets are considered to be a leading indicator for the macroeconomy (Akinsomi et al. 2016a). 


\section{References}

Akinsomi, Omokolade, Goodness C Aye, Vassilios Babalos, Fotini Economou, and Rangan Gupta. 2016. "Real estate returns predictability revisited: novel evidence from the US REITs market." Empirical Economics, 51 (3): 1165-1190.

Akinsomi, Omokolade, Mehmet Balcilar, Rıza Demirer, and Rangan Gupta. 2016. "The effect of gold market speculation on REIT returns in South Africa: a behavioral perspective." Journal of Economics and Finance, pp. 1-20.

Andersen, Torben G, Tim Bollerslev, Francis X Diebold, and Clara Vega. 2007. "Real-time price discovery in global stock, bond and foreign exchange markets." Journal of international Economics, 73 (2): 251-277.

Bai, Jushan and Pierre Perron. 2003. "Computation and analysis of multiple structural change models.” Journal of applied econometrics, 18 (1): 1-22.

Balduzzi, Pierluigi, Edwin J Elton, and T Clifton Green. 2001. "Economic news and bond prices: Evidence from the US Treasury market." Journal of financial and Quantitative analysis, 36 (04): 523-543.

Bekaert, Geert and Campbell R Harvey. 1995. "Time-varying world market integration.” The Journal of Finance, 50 (2): 403-444.

Bernanke, Ben S and Kenneth N Kuttner. 2005. "What explains the stock market's reaction to Federal Reserve policy?” The Journal of Finance, 60 (3): 1221-1257.

Bredin, Don, Gerard O'Reilly, and Simon Stevenson. 2011. "Monetary policy transmission and real estate investment trusts." International Journal of Finance \& Economics, 16 (1): 92-102.

Bredin, Don, Stuart Hyde, Dirk Nitzsche, and Gerard O'reilly. 2007. "UK stock returns and the impact of domestic monetary policy shocks." Journal of Business Finance \& Accounting, 34 (5-6): 872-888.

Cakan, Esin, Nadia Doytch, and Kamal P Upadhyaya. 2015. "Does US macroeconomic news make emerging financial markets riskier?” Borsa Istanbul Review, 15 (1): 37-43.

Campbell, John Y and Robert J Shiller. 1988. "The dividend-price ratio and expectations of future dividends and discount factors." The Review of Financial Studies, 1 (3): 195-228.

Campbell, John Y, Andrew Wen-Chuan Lo, and Archie Craig MacKinlay. 1997. The econometrics of financial markets, princeton University press.

Caporale, Guglielmo Maria, Ricardo M Sousa, and Mark E Wohar. 2016. "Can the ConsumptionWealth Ratio Predict Housing Returns? Evidence from OECD Countries." Real Estate Economics.

Chang, Kuang-Liang. 2017. "Does REIT index hedge inflation risk? New evidence from the tail quantile dependences of the Markov-switching GRG copula." The North American Journal of Economics and Finance, 39, 56-67.

Chen, Nai-Fu, Richard Roll, and Stephen A Ross. 1986. "Economic forces and the stock market." Journal of business, pp. 383-403.

Claus, Edda and Mardi Dungey. 2016. "Can monetary policy surprises affect the term structure?" Journal of Macroeconomics, 47, 68-83.

Claus, Edda, Iris Claus, Leo Krippner et al. 2014. "Asset markets and monetary policy shocks at the zero lower bound.” Technical Report, Centre for Applied Macroeconomic Analysis, Crawford School of Public Policy, The Australian National University. 
Cochrane, John H and Monika Piazzesi. 2002. "The Fed and interest rates: A high-frequency identification.” Technical Report, National Bureau of Economic Research.

Cook, Timothy and Thomas Hahn. 1989. "The effect of changes in the federal funds rate target on market interest rates in the 1970s." Journal of Monetary Economics, 24 (3): 331-351.

Cooley, Thomas F and Edward C Prescott. 1976. "Estimation in the presence of stochastic parameter variation.” Econometrica: journal of the Econometric Society, pp. 167-184.

Diebold, Francis X and Kamil Yilmaz. 2013. "Measuring the dynamics of global business cycle connectedness."

Diebold, Francis X and Kamil Yilmaz. 2015. Financial and Macroeconomic Connectedness: A Network Approach to Measurement and Monitoring, Oxford University Press, USA.

Ederington, Louis H and Jae Ha Lee. 1993. "How markets process information: News releases and volatility." The Journal of Finance, 48 (4): 1161-1191.

Fama, Eugene F and Kenneth R French. 1988. "Dividend yields and expected stock returns." Journal of financial economics, 22 (1): 3-25.

Ghysels, E, A Plazzi, WN Torous, and Valkanov RI. "Forecasting Real Estate Prices, Handbook of Economic Forecasting: Vol II,(G. Elliott and A. Timmermann, eds.).” 2012.

Ghysels, Eric, Alberto Plazzi, Rossen Valkanov, Walter Torous et al. 2013. "Forecasting Real Estate Prices." Handbook of Economic Forecasting, 2, 509-580.

Gürkaynak, Refet S, Brian P Sack, and Eric T Swanson. 2012. "Market-based measures of monetary policy expectations.” Journal of Business \& Economic Statistics.

Hanousek, Jan, Evžen Kočenda, and Ali M Kutan. 2009. "The reaction of asset prices to macroeconomic announcements in new EU markets: Evidence from intraday data." Journal of Financial Stability, 5 (2): 199-219.

Hausman, Joshua and Jon Wongswan. 2011. "Global asset prices and FOMC announcements." Journal of International Money and Finance, 30 (3): 547-571.

Hong, Gwangheon and Bong Soo Lee. 2013. "Does Inflation Illusion Explain the Relation between REITs and Inflation?” The Journal of Real Estate Finance and Economics, 47 (1): 123-151.

Ji, Qiang and Jian-Feng Guo. 2015. "Market interdependence among commodity prices based on information transmission on the Internet." Physica A: Statistical Mechanics and its Applications, 426, 35-44.

Ji, Qiang and Ying Fan. 2016. "Evolution of the world crude oil market integration: A graph theory analysis.” Energy Economics, 53, 90-100.

Kishor, N Kundan and Hardik A Marfatia. 2013. "The time-varying response of foreign stock markets to US monetary policy surprises: Evidence from the Federal funds futures market." Journal of International Financial Markets, Institutions and Money, 24, 1-24.

Kroencke, Tim A, Felix Schindler, and Bertram I Steininger. 2016. "Time-varying Macroeconomic Risk of Real Estate Returns."

Krueger, Joel T and Kenneth N Kuttner. 1996. "The fed funds futures rate as a predictor of Federal Reserve policy." Journal of Futures Markets, 16 (8): 865-879.

Kuttner, Kenneth N. 2001. "Monetary policy surprises and interest rates: Evidence from the Fed funds futures market.” Journal of monetary economics, 47 (3): 523-544. 
Liu, Jing, Geoffrey Loudon, and George Milunovich. 2012. "Linkages between international REITs: the role of economic factors.” Journal of Property Investment \& Finance, 30 (5): 473-492.

Lu, Chiuling, Yiuman Tse, and Michael Williams. 2013. "Returns transmission, value at risk, and diversification benefits in international REITs: evidence from the financial crisis." Review of quantitative finance and accounting, 40 (2): 293-318.

Ntuli, Mpilo and Omokolade Akinsomi. 2016. "An Overview of the Initial Performance of the South African REITs Market.” Available at SSRN: https://ssrn.com/abstract=2846090.

Ooi, Joseph TL, Seow-Eng Ong, and Poh-Har Neo. 2011. "The wealth effects of property acquisitions: evidence from Japanese and Singaporean REITs.” Real Estate Economics, 39 (3): 487-505.

Rigobon, Roberto and Brian Sack. 2004. "The impact of monetary policy on asset prices." Journal of Monetary Economics, 51 (8): 1553-1575.

Scotti, Chiara. 2016. "Surprise and uncertainty indexes: Real-time aggregation of real-activity macro-surprises." Journal of Monetary Economics, 82, 1-19.

$\mathrm{Xu}$, Pisun and Jian Yang. 2011. "US monetary policy surprises and international securitized real estate markets.” The Journal of Real Estate Finance and Economics, 43 (4): 459-490.

Yilmaz, Kamil. 2010. "Return and volatility spillovers among the East Asian equity markets." Journal of Asian Economics, 21 (3): 304-313.

Yunus, Nafeesa. 2009. "Increasing convergence between US and international securitized property markets: evidence based on cointegration tests." Real Estate Economics, 37 (3): 383-411. 
Table 1: Summary Statistics

The table presents the summary statistics for the U.S. monetary policy and macroeconomic surprises.

\begin{tabular}{l||rrrrr}
\hline Variable & Obs & Min & Max & Avg & S.D. \\
\hline Monetary Policy Surprise & 116 & -36.00 & 15.00 & -0.931 & 7.127 \\
Inflation Surprise & 257 & -3.072 & 3.072 & -0.080 & 0.980 \\
Unemployment Surprise & 257 & -2.592 & 2.592 & -0.239 & 0.999 \\
\hline
\end{tabular}


Table 2: Benchmark OLS Estimates and Evidence of Structural Instability

The table presents the fixed coefficient OLS estimates (col 2-3) and the estimates of the structural break model (Col 4-8) showing the response of international REIT stock returns due to the U.S. monetary policy surprise (Panel A ), inflation surprise (Panel B), and unemployment surprise (Panel C).

\begin{tabular}{|c|c|c|c|c|}
\hline \multirow[b]{3}{*}{ REIT } & \multirow{2}{*}{$\begin{array}{l}\text { OLS } \\
\text { Full Sample }\end{array}$} & \multicolumn{2}{|c|}{ OLS with Structural Breaks } & \multirow[b]{2}{*}{ Sample II } \\
\hline & & Sample I & Break Date & \\
\hline & P-Val & P-Val & & Surp \\
\hline
\end{tabular}

Panel A: Monetary Policy Surprise

\begin{tabular}{l||cc||cc|c|cc}
\hline Australia & 0.059 & 0.57 & 0.194 & 0.11 & Dec-05 & -0.050 & 0.86 \\
Belgium & 0.023 & 0.73 & -0.219 & 0.26 & Nov-97 & 0.183 & 0.22 \\
Canada & -0.055 & 0.44 & -0.171 & 0.19 & Jan-06 & -0.645 & 0.03 \\
France & 0.045 & 0.70 & 0.427 & 0.33 & Oct-07 & 1.353 & 0.17 \\
Japan & -0.195 & 0.12 & 0.667 & 0.11 & Dec-05 & -0.206 & 0.50 \\
Netherlands & 0.036 & 0.64 & 0.005 & 0.97 & Aug-05 & -0.027 & 0.92 \\
New Zealand & -0.054 & 0.58 & 0.728 & 0.02 & Dec-00 & -0.133 & 0.54 \\
U.S. & -0.092 & 0.36 & 0.114 & 0.27 & Nov-05 & -0.473 & 0.05
\end{tabular}

Panel B: Inflation Surprise

\begin{tabular}{l||cc||cc|c|cc}
\hline Australia & 0.019 & 0.90 & -0.223 & 0.11 & Jan-08 & 0.368 & 0.03 \\
Belgium & 0.044 & 0.53 & -0.120 & 0.37 & May-02 & 0.106 & 0.23 \\
Canada & -0.055 & 0.61 & -0.393 & 0.00 & Nov-05 & 0.228 & 0.04 \\
France & -0.029 & 0.86 & -0.337 & 0.05 & Sep-08 & 0.344 & 0.07 \\
Japan & -0.005 & 0.96 & -0.089 & 0.39 & May-13 & 0.658 & 0.03 \\
Netherlands & 0.046 & 0.54 & 0.121 & 0.15 & Apr-11 & -0.305 & 0.10 \\
New Zealand & 0.034 & 0.74 & 0.185 & 0.14 & Dec-08 & -0.281 & 0.11 \\
U.S. & 0.000 & 1.00 & 0.232 & 0.09 & Dec-08 & -0.596 & 0.01
\end{tabular}

Panel C: Unemployment Surprise

\begin{tabular}{l||cc||cc|c|cc}
\hline Australia & 0.166 & 0.06 & -0.109 & 0.42 & Jul-08 & 0.271 & 0.08 \\
Belgium & 0.045 & 0.67 & 0.163 & 0.10 & Aug-07 & -0.106 & 0.26 \\
Canada & -0.242 & 0.02 & 0.048 & 0.67 & Jan-08 & -0.153 & 0.15 \\
France & 0.288 & 0.31 & 0.260 & 0.49 & Aug-07 & 0.014 & 0.92 \\
Japan & 0.115 & 0.62 & -0.165 & 0.14 & Aug-13 & -0.367 & 0.27 \\
Netherlands & 0.014 & 0.86 & 0.131 & 0.15 & Oct-11 & -0.431 & 0.03 \\
New Zealand & 0.142 & 0.48 & -0.261 & 0.05 & Sep-09 & 0.228 & 0.12 \\
U.S. & 0.024 & 0.77 & -0.173 & 0.19 & May-10 & -0.013 & 0.95
\end{tabular}


Table 3: Correlation Between Countries' Time Varying Response

The table presents the correlation coefficient between the REITs time-varying responses between countries to monetary policy surprise (Panel A), inflation surprise (Panel B), and unemployment surprise (Panel C).

\begin{tabular}{l||rrrrrrrr}
\hline \multicolumn{10}{c}{ Panel A: Monetary Policy Surprise } \\
\hline \multirow{2}{*}{ Australia } & AUS & BEL & CAN & FRA & JPN & NEH & NZD & USA \\
Belgium & 1 & & & & & & & \\
Canada & 0.85 & 1 & & & & & & \\
France & 0.88 & 0.70 & 1 & & & & & \\
Japan & 0.88 & 0.85 & 0.74 & 1 & & & & \\
Netherlands & 0.69 & 0.69 & 0.54 & 0.85 & 1 & & & \\
New Zealand & -0.41 & 0.35 & 0.59 & 0.77 & 0.38 & 1 & & \\
U.S. & 0.57 & 0.54 & 0.33 & 0.68 & 0.60 & 0.31 & 1 & \\
& -0.41 & -0.24 & 0.02 & 0.66 & 0.70 & 0.34 & 0.67 & 1
\end{tabular}

\begin{tabular}{l||rrrrrrrr}
\hline \multicolumn{10}{c}{ Panel B: Inflation Surprise } \\
\hline \multicolumn{1}{l|}{ Australia } & AUS & BEL & CAN & FRA & JPN & NEH & NZD & USA \\
Belgium & 1 & & & & & & & \\
Canada & 0.62 & 1 & & & & & & \\
France & 0.71 & 0.73 & 1 & & & & & \\
Japan & 0.41 & 0.42 & 0.77 & 1 & & & & \\
Netherlands & -0.17 & 0.06 & -0.42 & -0.49 & 1 & & & \\
New Zealand & 0.01 & -0.17 & 0.14 & 0.58 & -0.52 & 1 & & \\
U.S. & -0.22 & -0.40 & -0.27 & 0.11 & -0.13 & 0.31 & 1 & \\
& 0.62 & 0.47 & 0.66 & 0.48 & -0.31 & 0.04 & -0.10 & 1
\end{tabular}

\begin{tabular}{l||rrrrrrrr}
\hline \multicolumn{10}{c}{ Panel C: Unemployment Surprise } \\
\hline & AUS & BEL & CAN & FRA & JPN & NEH & NZD & USA \\
Australia & 1 & & & & & & & \\
Belgium & -0.38 & 1 & & & & & & \\
Canada & -0.15 & 0.81 & 1 & & & & & \\
France & 0.28 & 0.06 & 0.16 & 1 & & & & \\
Japan & 0.53 & -0.39 & -0.39 & 0.00 & 1 & & & \\
Netherlands & 0.00 & 0.69 & 0.37 & 0.16 & -0.24 & 1 & & \\
New Zealand & 0.75 & -0.75 & -0.49 & 0.29 & 0.40 & -0.52 & 1 & \\
U.S. & -0.43 & 0.75 & 0.75 & 0.12 & -0.31 & 0.41 & -0.64 & 1 \\
& & & & & & & &
\end{tabular}




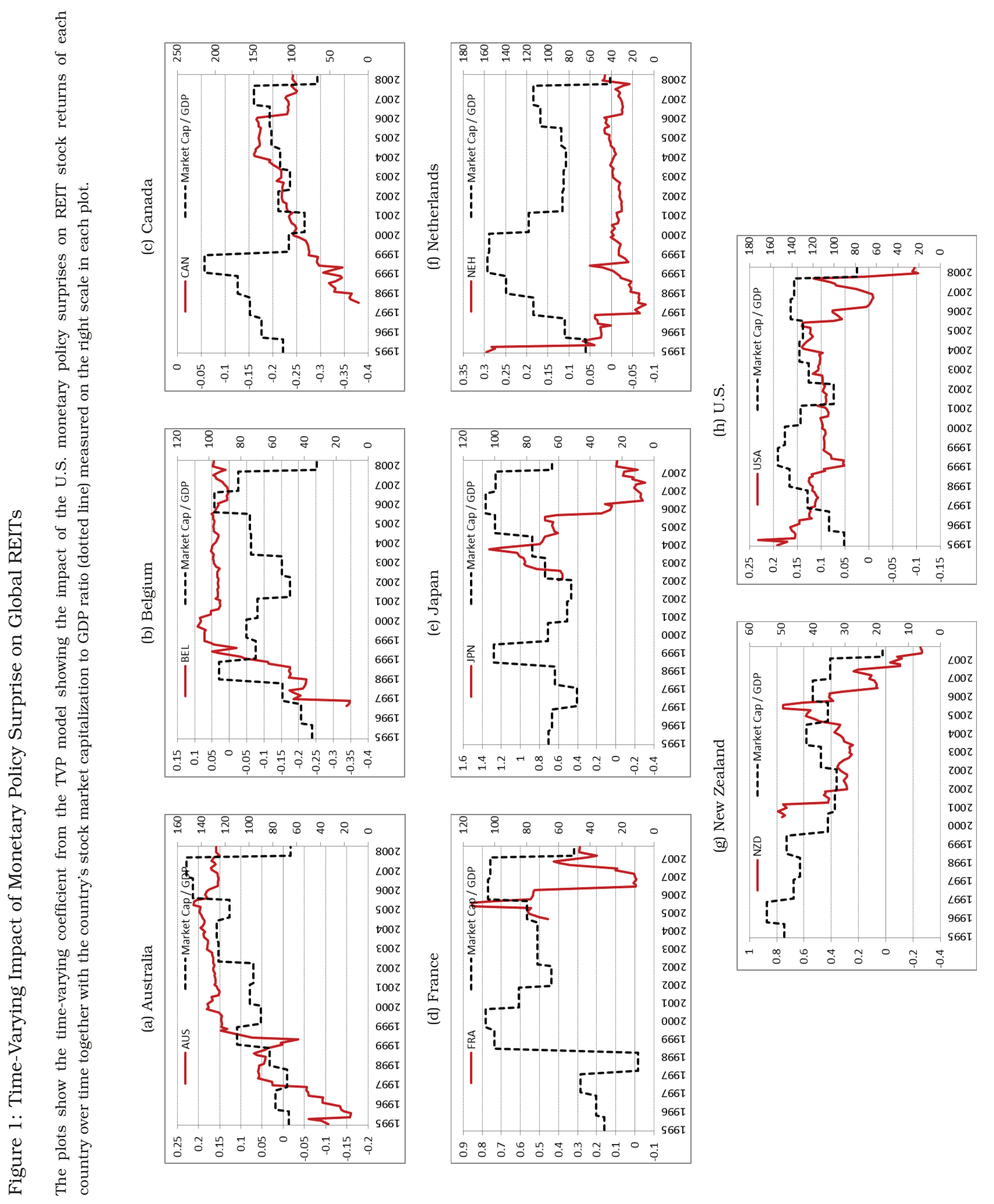



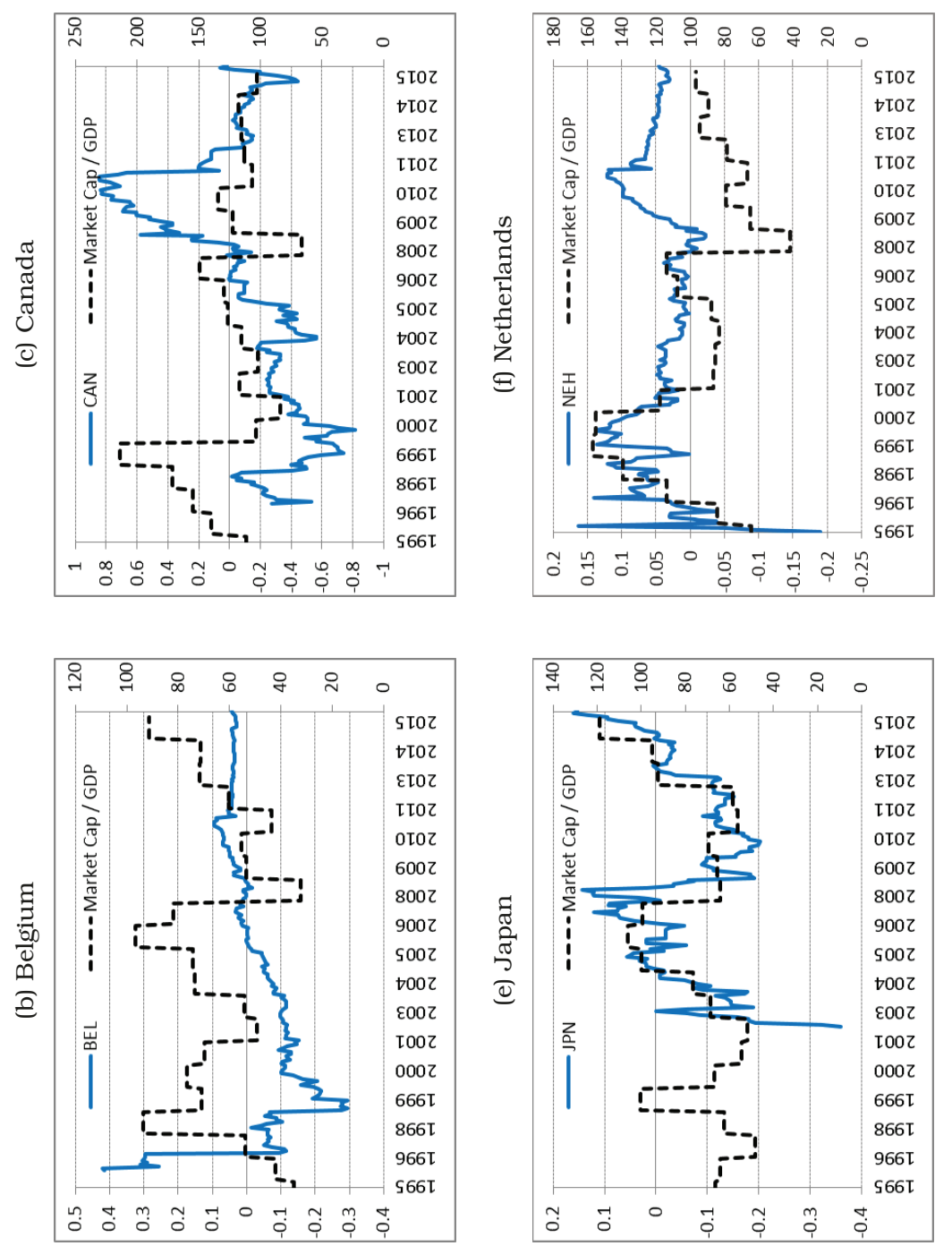

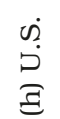
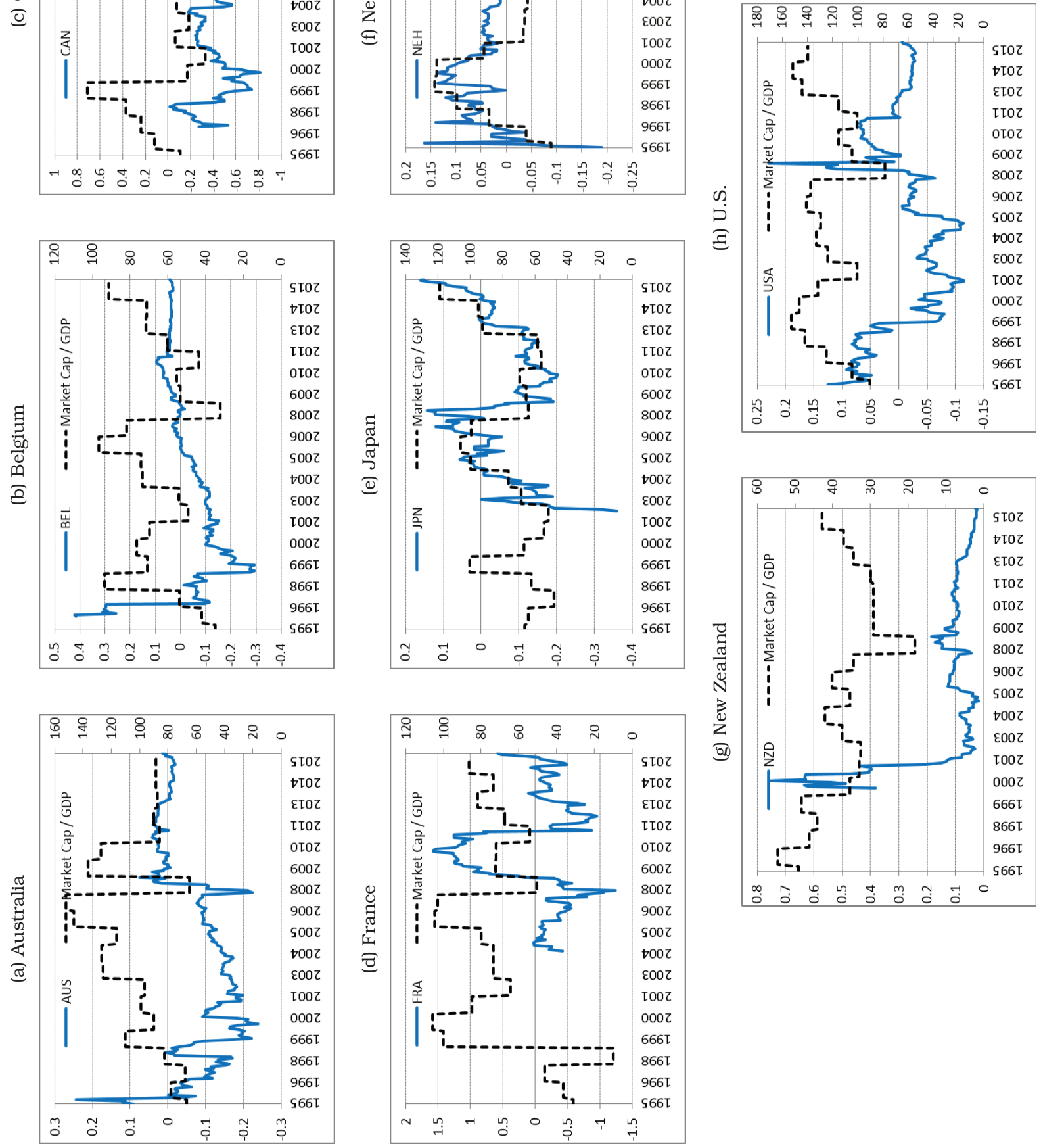

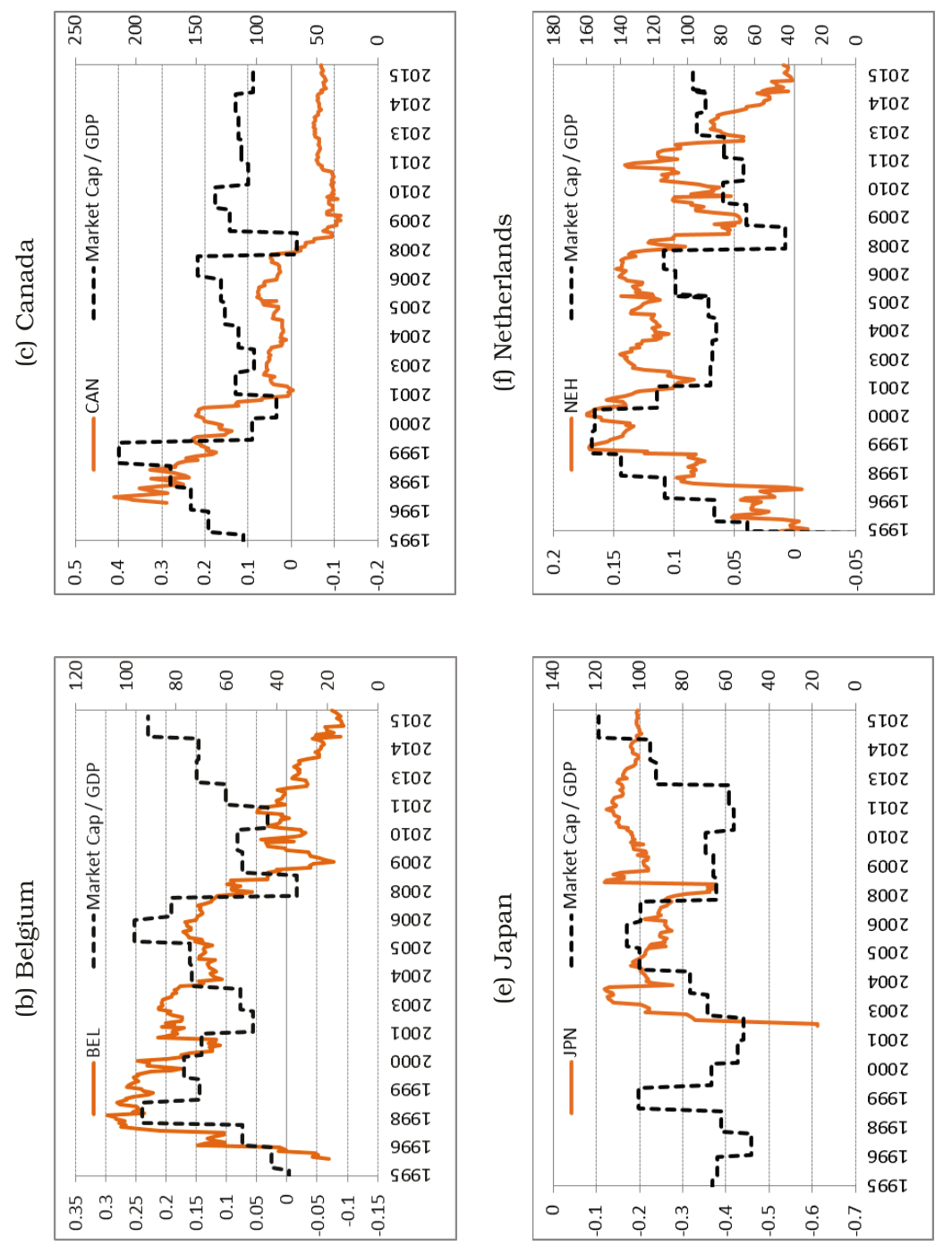

$\dot{\theta}$
$\stackrel{\Xi}{\Xi}$
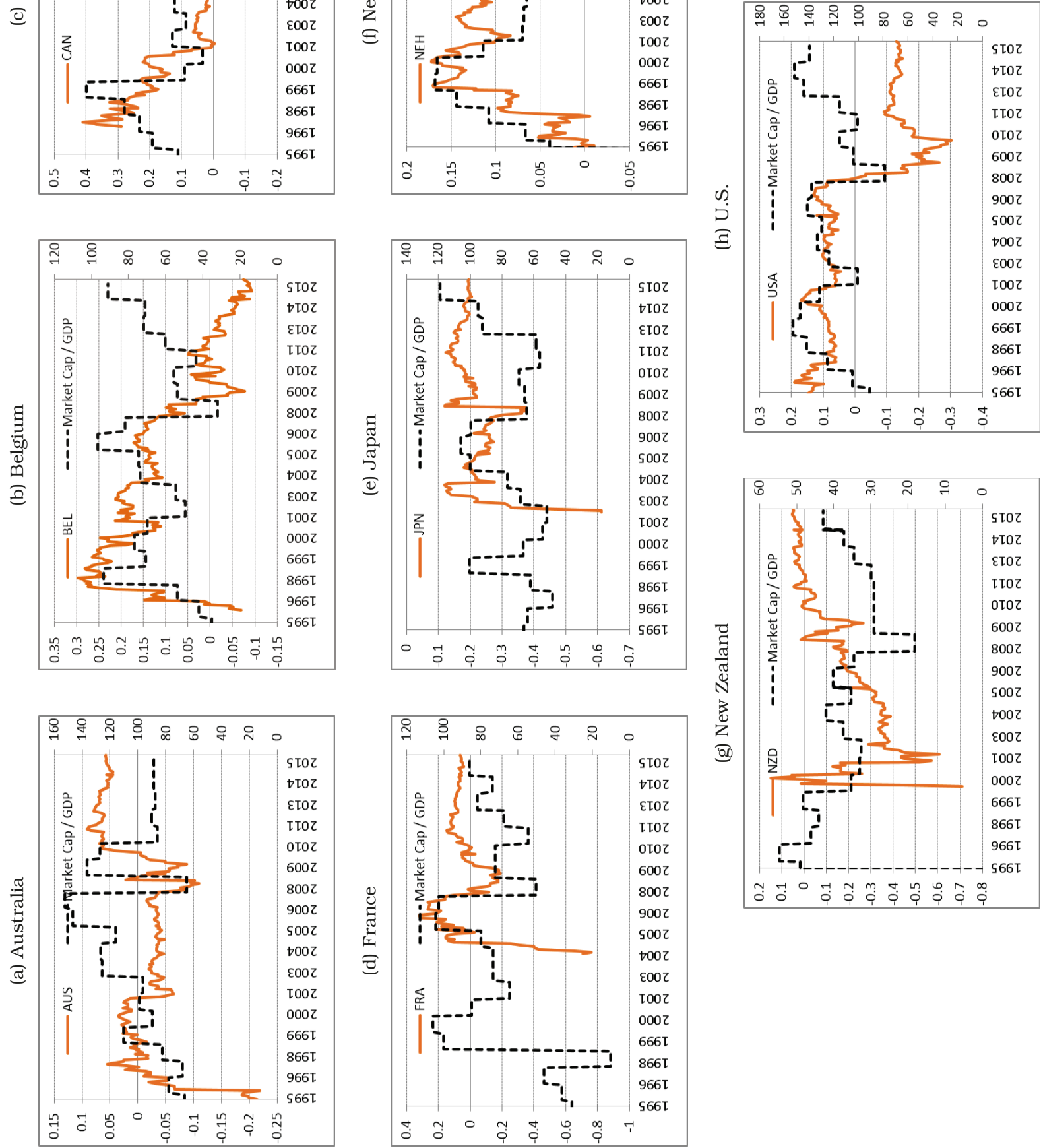